\title{
Influence Of Book Value Per Share, Net Income And Dividends To Merket Value Per Share On Manufacture Companies Listed In Indonesia Stock Exchange
}

\author{
Aulia Rahman Harahap
}

Department of Accounting, Univesity Of North Sumatra, Indonesia

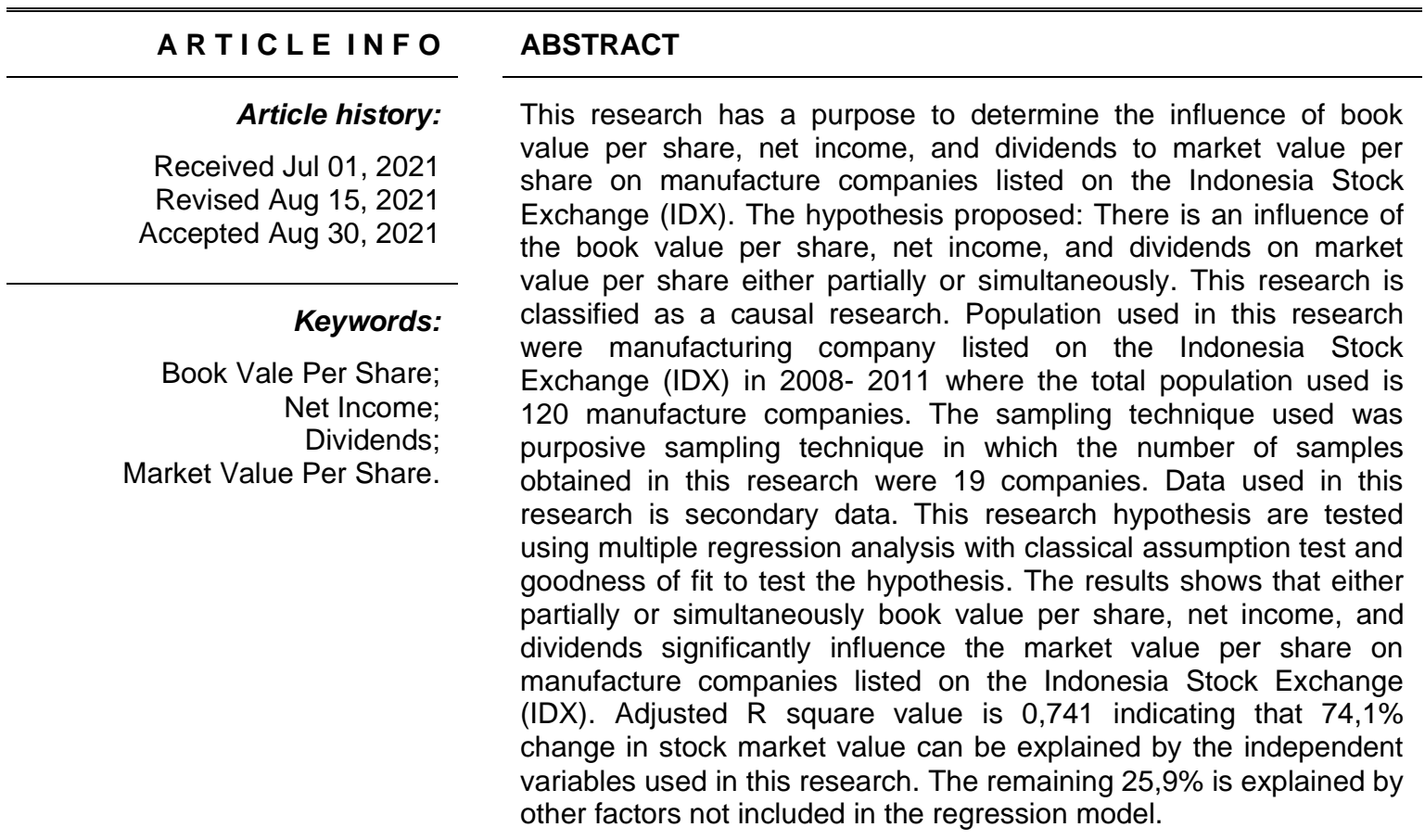

This is an open access article under the CC BY-NC license.

Corresponding Author:
Aulia Rahman Harahap,
Department of Accounting,
University Of North Sumatara, Indonesa,
J. Dr. Mansur No. 9 Padang Bulan, Kec. Medan Baru, Kota Medan 20222.
Email: auliaharahap@gmail.com
1. INTRODUCTION
Sources of company funding, can come from internal or external companies. The company's
internal source of funding comes from the company's owner's capital, while the company's external
source of funding comes from the sale of shares to investors. "Shares are an alternative source of
long-term funds for a company. Companies that need long-term funds in the form of equity can
obtain them through the issuance of shares either sold through private placements or through initial
public offerings" (Sudana, 2011: 87 ).
Investors need a place that makes it easy to choose various investment alternatives that suit
investors' wishes. On the other hand, the company also needs a place that allows it to obtain funds
to finance the company's activities and development, the capital market is a meeting place for
companies as parties that need funds and investors as parties who are willing to invest their funds


into the company, expecting returns. Efficient distribution of funds from investors to companies is also one of the vital roles of the capital market.

The phenomenon of increasing public interest in buying shares in the capital market, reflects that shares are starting to become the people's choice in making investments. The stock market capitalization in the last three years has increased significantly from year to year. Based on data from the Indonesia Stock Exchange in 2009 the market capitalization of the shares listed on the Indonesia Stock Exchange was Rp. 2,019.4 trillion, in 2010 amounting to Rp. 3,243.8 trillion, in 2011 amounting to Rp. 3,537 trillion and until the end of February 2012 of Rp. 3,754 trillion. The number of companies listed on the Indonesia Stock Exchange has also increased, in 2006 there were 342 companies listed, 354 companies in 2007, 393 companies in

in 2008, 399 companies in 2009, 413 companies in 2010, 439 companies in 2011 were listed and 442 companies in 2012 were listed on the IDX. Thus, it can be concluded that both companies and investors or the public have trusted the capital market as a means of bringing together companies that need funds with investors who have excess funds.

Supply theory explains the relationship between supply and price, the higher the supply, the cheaper the price of the good. In buying and selling shares this also applies, the higher the number of shares offered, the market price of these shares will decrease. If investors feel that the risk they get is higher than the return they get, investors will immediately release their shares and this causes the offer of certain shares to increase by itself, the market price of these shares will decrease. Investors will release their shareholdings if the company's performance is considered to be declining, a declining net income will make investors lose confidence in the company's performance and will cause investors to give up their share ownership.

The stock price describes the value of the company, the higher the stock price, the higher the value of the company and the company's prospects. according to Halim (2005: 21-29) stock prices are influenced by internal factors and external factors. Internal factors that affect stock prices relate to the specific nature of the stock (company performance and the industry in which the company operates). In addition, external factors that are macro in nature include macroeconomic conditions or market technical conditions, social and political conditions, developing issues, as well as regulations that are less favorable to the company.

Research on the effect of the book value of shares, net income and dividends on the market value of shares has been carried out by several researchers, namely Brief and Zarowin (1999) stating that book value and dividends have an explanatory power that is almost the same as book value and earnings, Mender \& Sprecher (in Natasyah 2000) states that the book value of shares, net working capital, EPS have a positive effect, while dividends have a negative effect on stock prices.

\section{RESEARCH METHOD}

This study uses a comparative causal research design. According to Kuncoro (2009: 16-17) comparative causal research is "research that shows the direction of the relationship between the independent variable and the dependent variable, in addition to measuring the strength of the relationship". This study analyzes the effect of the book value of shares, net income and dividends on the market value of the stock, where the book value of shares, net income and dividends are independent variables (independent variables), while stock market values are the dependent variable (dependent variable).

\subsection{Data Analysis Methods and Techniques}

\section{a. Multiple Regression Analysis}

Multiple regression analysis is an analysis to test the effect of two or more independent variables on the dependent variable with an interval or ratio measurement scale. This analysis was conducted to see the effect of the book value of shares, net income and dividends on the market value of shares (stock prices).

\subsection{Classic assumption test}

\section{a. Normality Test}


The normality test aims to "test whether in the regression model, the confounding or residual variables have a normal distribution. It is known that the $\mathrm{t}$-test and $\mathrm{F}$-test assume that the residual value follows a normal distribution. If this assumption is violated, the statistical test becomes invalid for a small sample size" (Ghozali, 2011: 160). To find out whether the residuals are normally distributed or not, that is by graphical analysis and statistical analysis. Normality can be detected by looking.

\section{b. Multicollinearity Test}

This test aims to "test whether the regression model found a correlation between independent variables" (Ghozali, 2011: 105). Correlation will not occur between independent variables if the regression model is good. If there is a correlation between the independent variables, the independent variable is not orthogonal. Orthogonal variables are independent variables whose correlation between independent variables is equal to zero. The presence or absence of multicollinearity can be detected by looking at the tolerance and variance inflation factor (VIF) values, as well as by analyzing the correlation matrix of the independent variables. The cut off value that is commonly used to indicate the presence of multicollinearity is if the VIF value is not 10 and the tolerance value is not less than 0.1 .

\section{c. Autocorrelation Test}

This test aims to "test whether in the linear regression model there is a correlation between the confounding error in the previous period (t-1). If there is a correlation, it is called an autocorrelation problem. Autocorrelation arises because successive observations over time are related to one another" (Ghozali, 2011: 110).

\section{d. Heteroscedasticity Test}

This test aims to test whether in the regression model there is an inequality of variance from the residual of one observation to another observation. If the variance is fixed, it is called homoscedasticity and if it is different it is called heteroscedasticity" (Ghozali, 2011: 139).

\section{RESULTS AND DISCUSSIONS}

\subsection{Analysis of Research Results}

\section{a. Descriptive Statistics}

Descriptive statistical analysis will provide an overview or description of a data seen from the minimum, maximum, average, and standard deviation values generated from the research variables. This study uses three independent variables, namely the book value of shares, net income, and dividends. The results of the analysis with descriptive statistics from a sample of manufacturing companies from 2008-2011 can be seen in the following table:

Table 1. Descriptive Statistics

Descriptive Statistics

\begin{tabular}{lccccc}
\hline & $\mathrm{N}$ & Minimum & Maximum & mean & Std. Deviation \\
\hline STOCK MARKET VALUE & 76 & 130.00 & 3640000.00 & 27855.0263 & 59144,17550 \\
SHARE BOOK VALUE & 76 & 10.00 & 1000000 & 474.2105 & 423.71142 \\
NET INCOME & 76 & $8.12 \mathrm{E} 8$ & $2.11 \mathrm{E} 13$ & $1.7938 \mathrm{E} 12$ & $3.52836 \mathrm{E} 12$ \\
DIVIDEND & 76 & 6.00 & 10000.00 & 1263.2895 & 2461.00828 \\
Valid N (listwise) & 76 & & & & \\
\hline
\end{tabular}

Source: SPSS Processing Results (2012)

Table 1 shows that the sample used in the study amounted to 76 , which can be seen from the value of N. Based on the data from table 4.1, it can be described as follows:

1) The stock market value variable (NPS) has a minimum value of 130.00 and a maximum value of 364000.00 with an average value of 27855.0263 and a standard deviation of 59144.17550. So it can be concluded that the minimum stock market value (NPS) of manufacturing companies that became the research sample from 2008 to 2011 was 130.00 and the maximum value of stock market value (NPS) was 364000.00 with an average of 27855.0263 and standard deviation of 59144,17550 . 
2) The stock book value (NBS) variable has a minimum value of 10.00 and a maximum value of 1000.00 with an average value of 474.2105 and a standard deviation of 243,71142 . the research sample from 2008 to 2011 was 10.00 and a maximum of 1000.00 with an average NPS of manufacturing companies studied at 474.2105 and a standard deviation of 243 , 71142. The variable net income (NI) has a minimum value of 8.112053000 .00 and a maximum value of 2.1077000000000 .00 with an average value of 1.793800000000000 and a standard deviation of 3.528360000000 . Which means that the minimum value of the net income $(\mathrm{NI})$ of manufacturing companies that became the research sample from 2008 to 2011 was 8.112053000 .00 and a maximum of 2.1077000000000.00 with an average $\mathrm{NI}$ of manufacturing companies studied at 1.793800000000000 and standard deviation of 3.528360000000

3) The dividend variable (DIV) has a minimum value of 6.00 and a maximum value of 10000.00 with an average value of 1263.2895 and a standard deviation of 2461.00828. Which means that the minimum value of dividends (DIV) of manufacturing companies that are the research sample from 2008 to 2011 is 6.00 with a maximum value of 10000.00 . The average dividend (DIV) of the manufacturing companies studied was 1263.2895 and the standard deviation was 2461.00828.

\subsection{Classical Assumption Test}

\section{a. Normality Test}

The normality test is used to detect whether the residuals are normally distributed or not, namely by performing graphical analysis and statistical tests. In graph analysis, if the histogram graph shows a normal distribution pattern and the normal graph plot spreads regularly following a diagonal line, then the data is normally distributed. The results of the analysis with the normality test from a sample of manufacturing companies for the period 2008-2011 are presented in the following figure:

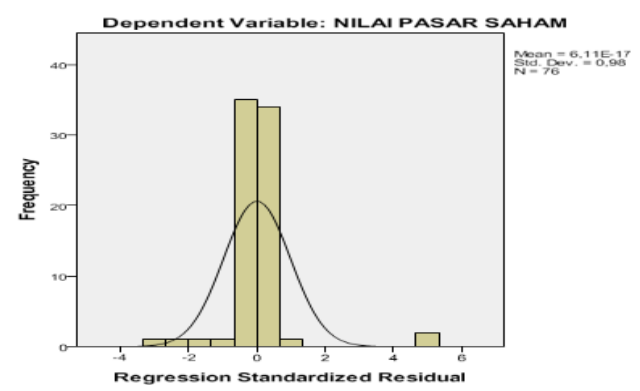

Figure 1. Histogram Graph

Figure 1 shows that the data is not normally distributed because the histogram graph does not show the distribution of the data following a diagonal line that does not skew to the left or right.

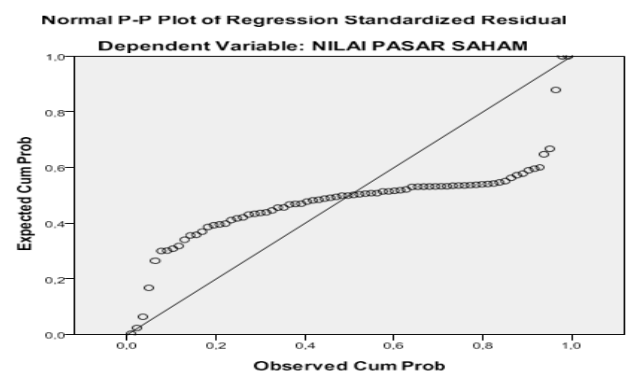

Figure 2. P-plot Normal Graph 
Figure 2 shows the normal p-plot graph showing the points tend to be close together and away from the diagonal line so that it can be concluded that the data in the regression model is not normally distributed.

For statistical tests, it can be done by looking at the value of Kolmogorov Smirnov, if the significance value is $>$ than 0.05 then the data is normally distributed. On the other hand, if the significance value is $<0.05$, then the data is not normally distributed. The results of statistical tests are shown in table 2 below:

Table 2. Kolmogorov-Smirnov. Test Results

One-Sample Kolmogorov-Smirnov Test

\begin{tabular}{ccc}
\hline & & Unstandardized Residual \\
\hline N & mean & 76 \\
Normal Parameters, b & Std. Deviation & 3.6800000 \\
Most Extreme Differences & Absolute &, 334 \\
& Positive &, 334 \\
& negative &,- 230 \\
Kolmogorov-Smirnov Z & & 2,913 \\
asymp. Sig. (2-tailed) & &, 000 \\
\hline
\end{tabular}

The results of the Kolmogorov Smirnov test, showed a significance value of 0.000 . Less than 0.05 then the data is not normally distributed. As discussed in chapter three, to change the regression model to normal, several methods can be used, including by transforming data into other forms, transforming data into natural logarithmic form, square root or logarithm 10. Transforming data into natural logarithmic form is carried out by researchers to normalize the data. Because in general, natural logarithms are mostly done by previous researchers so that the data is normally distributed. After doing the natural logarithm, the histogram graph and normal p-plot graph looks like this:

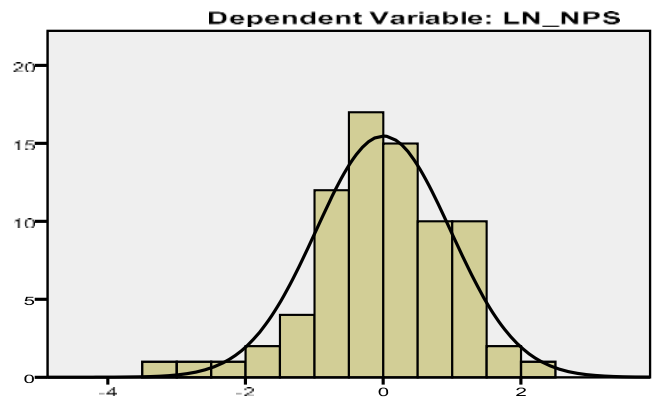

Figure 3. Histogram Graph After LN

Figure 3 shows that the data is normally distributed because the histogram shows the distribution of the data following a diagonal line that does not swerve to the left or to the right.

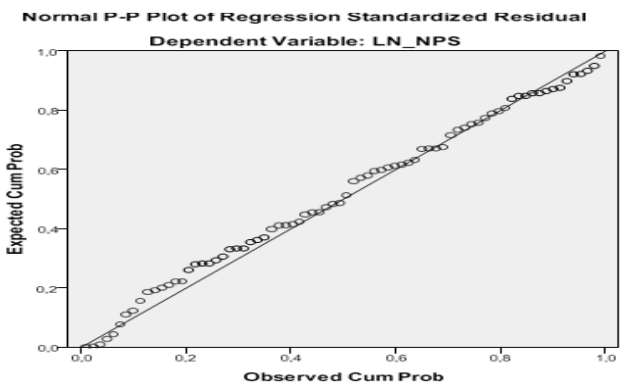

Figure 4. P-plot Normal Graph After LN 
Figure 4 shows the normal p-plot graph showing the points spread around the diagonal line and the distribution is close to the diagonal line so it can be concluded that the data in the regression model is normally distributed.

Table 3. Kolmogorov-Smirnov Test Results After LN

One-Sample Kolmogorov-Smirnov Test

\begin{tabular}{ccc}
\hline & & Unstandardized Residual \\
\hline $\mathrm{N}$ & mean & 76 \\
Normal Parameters, b &, 0000000 \\
& Std. Deviation &, 97218870 \\
Most Extreme Differences & Absolute &, 066 \\
& Positive & 0.040 \\
& negative &,- 066 \\
Kolmogorov-Smirnov Z & &, 575 \\
asymp. Sig. (2-tailed) &, 896 \\
\hline Source: SPSS Processing Results (2012)
\end{tabular}

Kolmogorov Smirnov's value shows a significance value of 0.896 , greater than 0.05 , the data is normally distributed.

\section{b. Multicollinearity Test}

The multicollinearity test was used to test whether the regression model found a correlation between the independent variables. This can be seen by looking at the tolerance and VIF of the processed data. The results of the multicollinearity test can be seen in table 4.4 below:

Table 4. Multicollinearity Test Coefficientsa

\begin{tabular}{|c|c|c|c|c|c|c|c|c|}
\hline & \multirow[t]{2}{*}{ Model } & \multicolumn{2}{|c|}{ Unstandardized Coefficients } & \multirow{2}{*}{$\begin{array}{c}\text { Standardized Coefficients } \\
\text { Beta }\end{array}$} & \multirow[t]{2}{*}{$t$} & \multirow[t]{2}{*}{ Sig. } & \multicolumn{2}{|c|}{ Collinearity Statistics } \\
\hline & & B & Std. Error & & & & Tolerance & VIF \\
\hline \multirow[t]{4}{*}{1} & (Constant) & $-7,624$ & 1,890 & & -4.035 &, 000 & & \\
\hline & LN_NBS & ,508 & 107 & ,352 & 4,735 &, 000 & ,624 & 1,603 \\
\hline & LN _NI & ,383 & ,062 & ,420 & 6,156 &, 000 & ,743 & 1.346 \\
\hline & LN DIV & 605 & 068 & 600 & 8,866 & ,000 & ,754 & 1.327 \\
\hline
\end{tabular}

Dependent Variable: LN_NPS

Source: SPSS Processing Results (2012)

Each independent variable used in this study shows a tolerance value greater than 0.10 , namely the stock book value variable has a tolerance value of 0.624 , the net income variable has a tolerance value of 0.743 , the dividend variable has a tolerance value of 0.754 when viewed from the VIF- In contrast, each independent variable shows a value less than 10, namely for VIF the book value of shares is 1.603 , VIF net income is 1.346 , VIF dividend is 1.327 . Thus it can be concluded that there is no symptom of multicollinearity in the independent variables.

Table 5. Correlation Coefficient Coefficient Correlationsa

\begin{tabular}{|c|c|c|c|c|c|}
\hline \multicolumn{3}{|c|}{ Model } & LN_DIV & LN_NI & LN_NBS \\
\hline \multirow[t]{6}{*}{1} & Correlations & LN_DIV & 1,000 &,- 310 &,- 491 \\
\hline & & LN_NI &,- 310 & 1,000 & ,502 \\
\hline & & LN_NBS &,- 491 & ,502 & 1,000 \\
\hline & Covariances & LN_DIV & ,005 &,- 001 &,- 004 \\
\hline & & LN_NI &,- 001 & ,004 & ,003 \\
\hline & & LN_NBS &,- 004 & ,003 & 0.012 \\
\hline
\end{tabular}

Dependent Variable: LN_NPS

Source: SPSS Processing (2012)

In table 5 it can be seen that the results of the correlation between the independent variables show that only the dividend variable has a fairly high correlation with the stock book value variable 
with a correlation level of -0.491 or around $49.1 \%$. Because this correlation is still below $95 \%$, it can be concluded that there is no multicollinearity, so the research can be continued.

\section{c. Heteroscedasticity Test}

The heteroscedasticity test aims to test whether in the regression model there is an inequality of variance from the residuals of one observation to another observation. To test the presence of heteroscedasticity, it can be done by observing the scatterplot graph which is presented as follows:

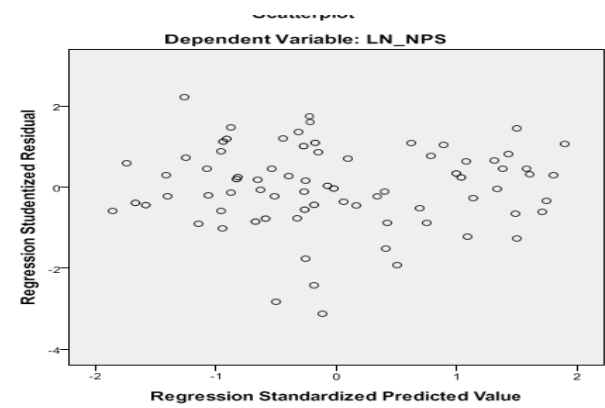

Figure 5. Heteroscedasticity Test Plot Graph

\section{d. Autocorrelation}

This test aims to see whether in the linear regression model there is a correlation between the confounding error in period $t$ and the error period t-1 (previous). A good regression model is one that is free from autocorrelation. To determine the presence or absence of autocorrelation can be done through the Durbin-Watson (DW) test with the following criteria:

1) $\mathrm{DW}<-2$ means there is autocorrelation

2) DW number between -2 to +2 means there is no autocorrelation

3) DW number $>+2$ means that there is a negative autocorrelation

\subsection{Research Hypothesis Testing}

\section{a. Coefficient of Determination (R2)}

The coefficient of determination (R2) is used to measure the model's ability to explain the variation of the independent variables. The following is the result of calculating the coefficient of determination of the hypothesis.

In the coefficient of determination of the regression model, the adjusted $\mathrm{R}$ square value is 0.741 . This means that the magnitude of the effect given by the book value of shares, net income, and dividends on the stock market value is $74.1 \%$. While the remaining $25.9 \%$ is influenced by other factors not examined in this study.

\section{b. Simultaneous Significance Test (F Test)}

The $\mathrm{F}$ test aims to test the independent variables used in the regression model whether they have a simultaneous effect on the variables studied (the dependent variable). The significance of the regression model was simultaneously tested by looking at the significance value (sig). Where if the sig value is below 0.05 then the independent variables jointly affect the dependent variable. The following are the results of the hypothesis for the $F$ test:

$\mathrm{HO}$ : There is no influence between the book value of shares, net income, and dividends on the market value of shares.

$\mathrm{Ha}$ : There is an effect between the variable book value of shares, net income, and dividends on the market value of shares.

The $\mathrm{F}$ test is performed by comparing the $\mathrm{P}$-value of $\mathrm{F}$ with . The conclusions that can be drawn from this $F$ test are:

1) If P-value $>$ from $=5 \%$ then $\mathrm{HO}$ is accepted and $\mathrm{Ha}$ is rejected. This means that the independent variables together have no significant effect on the dependent variable.

2) If the P-value $<$ of $=5 \%$ then $\mathrm{Ho}$ is rejected and $\mathrm{Ha}$ is accepted. This means that the independent variables together have a significant effect on the dependent variable. 
The results of the $\mathrm{F}$ test are as follows:

\begin{tabular}{|c|c|c|c|c|c|c|}
\hline & Model & Sum of Squares & $\mathrm{df}$ & Mean Square & $\mathrm{F}$ & Sig. \\
\hline 1 & $\begin{array}{c}\text { Regression } \\
\text { Residual } \\
\text { Total }\end{array}$ & $\begin{array}{c}213.975 \\
70.886 \\
284.861\end{array}$ & $\begin{array}{c}3 \\
72 \\
75\end{array}$ & $\begin{array}{c}71.325 \\
, 985\end{array}$ & 72.445 &, $000 a$ \\
\hline
\end{tabular}

Source: SPSS Processing Results (2012)

Based on the results of the F test in table 6 , it can be seen that the P-value or significance level is 0.000 which is smaller than $=0.05$. Based on these results, it can be concluded that $\mathrm{H} 0$ is accepted and $\mathrm{Ha}$ is rejected. This shows that the book value of shares, net income, and dividends simultaneously (simultaneously) affect the stock market value.

\section{c. Partial Significance Test (t Test)}

The t-test was conducted to test the effect of the independent variables partially on the dependent variable. The results of the t test are as follows:

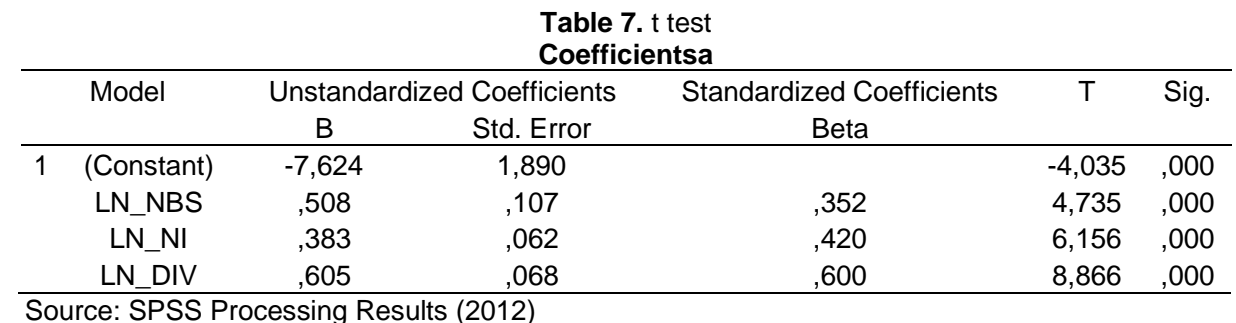

Based on the results of the t-test in the table, it can be concluded that the book value of shares, net income, and dividends have a significant effect on the stock market value partially or individually, this is evidenced by the significance value of each independent variable which is below 0 , 05. From the table, the multiple regression model can be obtained as follows: NPS $=-7.624+$ $0.508 \mathrm{NBS}+0.383 \mathrm{NI}+0.605 \mathrm{DIV}$

Information :

1) The constant coefficient based on the regression results is -7.624 , meaning that the market value of the stock will be -7.624 if the book value of shares, net income, and dividends are each 0 .

2) The regression coefficient of 0.508 NBS states that for every addition of one stock book value, the stock market value will increase by 0.508 .

3) The regression coefficient of $0.383 \mathrm{NI}$ states that each addition of one net income then the stock market value will increase by 0.383 .

4) The regression coefficient of 0.605 DIV states that for every addition of one dividend, the market value of the stock will increase by 0.605 .

\section{CONCLUSION}

Partially, the results show that the significance value of the t-test for book value of shares, net income, and dividends is $0.000,0.000$ and 0.000 , respectively, where the $\mathrm{t}$-count value is smaller than the t-table value. The significance number which is smaller than 0.05 indicates that each (partially) independent variable has a significant effect on the dependent variable.

Taken together (simultaneously), the results show that the book value of shares, net income, and dividends have a significant effect on the market value of the stock at the $95 \%$ confidence level. This is indicated by the significance number of the F-test results, which is 0.000 . This probability (significance) number is less than 0.05 , so the independent variables in the regression simultaneously have a significant effect on the dependent variable. 


\section{REFERENCES}

Aliminsyah dan Padji, 2007. Kamus Istilah Akuntansi, Yrama Widya, Bandung. Anggono, Alexander dan Zaki Baridwan, 2003. "Pengaruh Kebijakan Pembagian

Dividen, Nilai Buku, dan Laba". Simposium Nasional Akuntansi VI, Surabaya, hal 393-407.

Belkaoui, Ahmed Riahi, 2007, Teori Akuntansi, Edisi 5, Buku satu, Salemba 4, Jakarta.

Brief, R.P. and P. Zarowin, 1991. "The Value Relevance of Dividends, Books Value and Earnings", Working Paper, New York University.

Brigham, Eugene F dan Joel F. Houston, 1999. Manajemen Keuangan, Edisi Kedelapan, Buku 2, Erlangga, Jakarta.

Darmadji, Tjiptono dan Hendry M. Fahkruddin, 2011. Pasar Modal di Indonesia, Edisi 3, Salemba 4. Jakarta.

Febriani, Sry Rahayu, 2005. "Pengaruh Laba Akuntansi, Dividen, Dan Penjualan Terhadap Harga Saham Perusahaan Terbuka Di Bursa Efek Jakarta". Skripsi, Fakultas Ekonomi Universitas Sumatera Utara.

Ghozali, Farhan, 2005. "Faktor-faktor Yang Mempengaruhi Harga Saham Pada Perusahaan Manufaktur di Bursa Efek Surabaya". Jurnal Aplikasi Manajemen, Volume 3 Nomor 3 hal 294-300.

Ghozali, Imam, 2011. Aplikasi Analisis Multivariat Dengan SPSS, Edisi Kelima, Badan Penerbit Universitas Diponogoro, Semarang.

Gunistiyo dan Sumarno, 2009. "Pengaruh Book Value Per Share Terhadap Return Saham LQ-45 Di Bursa Efek Indonesia". Laporan Penelitian, Fakultas ekonomi Universitas Pancasakti Tegal.

Halim, Abdul, 2005. Analisis Investasi, Edisi 2, Salemba 4, Jakarta.

Hartono, Jogiyanto, 2010. Teori Portopolio dan Analisis Investasi, Edisi tujuh, BPFE, Yogyakarta.

Husnan, Suad dan Enny Pudjiastuti, 2006. Dasar-dasar Manajemen Keuangan, Edisi Kelima, UPP STIM YKPN, Yogyakarta.

Kuncoro, Mudrajad, 2009. Metode Riset untuk Bisnis dan Ekonomi Bagaimana Meneliti dan menulis tesis, Edisi 3, Erlangga, Jakarta.

Linda dan Fazli Syam BZ, 2005. "Hubungan Laba Akuntansi, Nilai Buku, dan Total Arus Kas dengan Market Value: Studi Akuntansi Relevansi Nilai”, Jurnal Riset Akuntansi Indonesia. Volume 8, Nomor 3 hal 286306.

Natasyah, Syahib, 2000. "Analisis Pengaruh Beberapa Faktor Fundamental dan Resiko Sistematik Terhadap Harga Saham Kasus Industri Barang Konsumsi Yang Go Publik di Pasar Modal Indonesia”, Vol. 15 No.3, hal 924-312.

Niswonger, Warren, Reeve, Fees, 1999. Prinsip-prinsip Akuntansi, Edisi 19, Jilid 1, Erlangga, Jakarta.

Samsul, Mohamad, 2006. Pasar Modal dan Manajemen Portofolio, Erlangga. Jakarta.

Sharpe, Wiliam F, Alexander, Gordon J dan Jeffery V. Bailey, 2006. Investasi, Edisi Keenam, Jilid 2, Indeks, Jakarta.

Soemarso, S,R, 2004. Akuntansi Suatu Pengantar, Buku 2, Edisi 5, Salemba 4, Jakarta

Subiyanto, Edi dan Fransisca Andreani, 2003. "Analisis Faktor-faktor yang Mempengaruhi Harga Saham", Jurnal Manajemen dan Kewirausahaan. Volume 5 Nomor 2 hal 171-180.

Subrata, Yuda, 2010. "Pengaruh Earning Per Share Dan Dividend Per Share Terhadap Harga Saham Pada Perusahaan Manufaktur Yang Terdaftar Di Bursa Efek Indonesia". Skripsi, Fakultas Ekonomi Universitas Sumatera Utara

Sudana, I Made, 2011. Manajemen Keuangan Perusahaan Teori dan Praktik, Erlangga, Jakarta.

Sukirno, Sandono, 2006. Teori Pengantar Makro Ekonomi, Edisi Ketiga, Rajawali Pers, Jakarta.

Sunariyah, 2006. Pengantar Pengetahuan Pasar Modal, Edisi Kelima, UPP STIM YKPN, Yogyakarta.

Wedari, Linda Kusumaning, 2006. "Pengaruh Kualitas Akrual dan Ukuran Perusahaan Terhadap Relevansi Nilai Antara Dividen, Nilai Buku dan Laba", Akuntansi dan Teknologi Informasi Informasi. Volume 5 Nomor 2 hal 83-98.

Weygandt, Jerry J, Kieso, Donald E dan Paul D. Kimmel, 2008. Accounting Principles, Buku 2, Salemba 4, Jakarta.

Winata, I, Komang, 2003. "Pengaruh Kebijakan Dividen Terhadap Harga Saham Perusahaan Manufaktur di Indonesia yang Masuk Bursa Efek Jakarta”. Jurnal Manajemen Keuangan, Volume 1 Nomor 2, hal 1725.

Zen, Fadia, 2009. "Earning Per Share, Book Value, Ecomonic Value Added dan Harga Saham". Jurnal Manajemen Gajayana, Volume 6, Nomor 2, hal 151-162. 